\title{
Pengaruh Citra Toko Terhadap Kepuasan Pelanggan Berbelanja Pada Distro Battleboom Store Di Kota Palu
}

\author{
Masjaya Kamaliono \\ Rosida P. Adam \\ Syamsul Bahri Dg. Parani \\ Jurusan Manajemen, Fakultas Ekonomi, Universitas Tadulako \\ Email: jayakamaliono@gmail.com
}

\begin{abstract}
The purpose of this study is to find out the influence of store image, consisting of store location, product, price, service, promotion, and physical facilities, on customers' shopping satisfaction at The Battleboom Store in Palu City. Type of research is quantitative. Sample consists of 100 respondents who shopped at The Battleboom Store in Palu City, who selected with a non-probability sampling technique, named purposive sampling. Method of analysis is multiple linear regressions. The result shows that store image simultaneously affects customer satisfaction. However, there are two dimensions of store image that are store location and physical facilities that have non-significant influence on customers' shopping satisfaction at The Battleboom Store in Palu City.
\end{abstract}

Keywords: store images, customer satisfaction

ABSTRAK
Tujuan penelitian ini adalah untuk mengetahui pengaruh dari variabel citra toko yang terdiri dari lokasi toko, produk, harga, pelayanan, promosi, dan fasilitas fisik terhadap kepuasan pelanggan berbelanja pada Battleboom Store di Kota Palu. Jenis Penelitian yang digunakan bersifat kuantitatif. Sampel yang digunakan dalam penelitiaan ini sebanyak 100 responden yang merupakan konsumen yang pernah berbelanja pada Battleboom Store di Kota Palu. Teknik pengambilan sampel untuk menentukan sampel yang akan digunakan dalam penelitian ini menggunakan Teknik non probability sampling, yaitu purposive sampling. Metode yang digunakan untuk menguji hipotesis adalah regresi linear berganda. Hasil penelitian menunjukkan variabel citra toko berpengaruh secara serempak terhadap kepuasan pelanggan. Namun, terdapat dua dimensi dari variabel citra toko yaitu lokasi toko dan fasilitas fisik yang berpengaruh tidak signifikan terhadap kepuasan pelanggan berbelanja pada Battleboom Store di Kota Palu.

Kata Kunci: Citra Toko, Kepuasan Pelanggan

\section{PENDAHULUAN}

Zaman yang semakin modern membuat usaha tempat perbelanjaan seperti Distro (distribution store) pada saat ini berkembang sangat pesat, sehingga persaingan tempat perbelanjaan menjadi sangat kompetitif. Hal ini menunjukkan adanya perubahan perilaku konsumen karena mulai tertarik untuk berbelanja di tempat yang dirasa lebih nyaman, selain itu atribut-atribut yang ditawarkan oleh toko distro cukup menarik hati konsumen. Hal ini menuntut para pelaku bisnis ritel distro tersebut untuk menyusun strategi yang tepat agar dapat merebut perhatian konsumen dan membangun serta mempertahankan kepuasan pelanggannya.

Salah satu strategi agar suatu ritel atau toko mampu bersaing dan bertahan dalam pasar adalah dengan menciptakan dan mempertahankan citra toko yang baik di mata konsumen maupun publik. Citra sebuah toko menurut Sopiah dan Syihabudhin (2008:138) adalah kepribadian sebuah toko. Menurut Kotler dan Amstrong (2004:442), dalam Foster (2008:50), terdapat 6 variabel citra toko yaitu lokasi toko, produk, harga, pelayanan, promosi dan fasilitas fisik. Maka untuk menjaga citra toko, toko harus memperhatikan faktor-faktor pembentuk citra toko, seperti kualitas produk, harga, kualitas layanan, lokasi toko, promosi dan fasilitas fisik yang dimiliki oleh toko. Citra toko yang positif akan membuat konsumen tertarik untuk berkunjung ke toko dan melakukan pembelian. 
Kamaliono, M.

Toko harus menentukan harga dengan tepat dan sesuai segmentasi pasar yang menjadi sasaran penjualan dan promosi yang baik untuk meningkatkan penjualan. Pemilihan lokasi harus strategis dimana lokasi mudah dijangkau oleh konsumen. Kualitas pelayanan juga merupakan salah satu aspek dalam menciptakan citra toko dengan cara memilih karyawan yang ramah dan selalu tersenyum, menghadapi konsumen dengan sabar dan mengetahui semua jenis produk yang dijual toko sehingga dapat melayani konsumen dengan baik dan benar. Toko harus menyediakan fasilitas fisik yang membuat konsumen nyaman pada saat berbelanja seperti lapangan parkir yang luas dan aman, menyediakan pendingin ruangan dan musik-musik yang enak didengar (Berman et al 2009).

Sulawesi Tengah khususnya di Kota Palu sendiri saat ini terdapat banyak distro yang dapat ditemui, salah satunya adalah Battleboom Store yang terletak di jalan Diponegoro No. 28 Palu. Battleboom Store merupakan distro yang memiliki desain tempat yang menarik dan beberapa fasilitas yang dapat membuat konsumen merasa nyaman dalam memilih produk yang ingin dibeli oleh konsumen.

Battleboom Store memilih produk dalam negeri untuk dipasarkan, karena produk dalam negeri memiliki kualitas yang beragam dan terdapat banyak macam model dan desain yang menarik, sehingga dapat menarik dan memberikan rasa kepercayaan dan kepuasan bagi pelanggannya. Kecenderungan konsumen untuk berpindah-pindah tempat dalam berbelanja kemungkinan karena pernah tidak mendapatkan citra yang baik pada tempat berbelanja tersebut.

Berdasarkan pada latar belakang yang telah dijelaskan maka peneliti mengemukakan rumusan masalah dalam penelitian ini yaitu: (1) Apakah citra toko yang terdiri dari lokasi toko, produk, harga, pelayanan, promosi dan fasilitas fisik secara serempak berpengaruh signifikan terhadap kepuasan pelanggan berbelanja di Battleboom Store Kota Palu, (2) Apakah lokasi toko berpengaruh signifikan terhadap kepuasan pelanggan berbelanja di Battleboom Store Kota Palu, (3) Apakah produk berpengaruh signifikan terhadap kepuasan pelanggan berbelanja di Battleboom Store Kota Palu, (4) 4. Apakah harga berpengaruh signifikan terhadap kepuasan pelanggan berbelanja di Battleboom Store Kota Palu, (5) Apakah pelayanan berpengaruh signifikan terhadap kepuasan pelanggan berbelanja di Battleboom Store Kota Palu, (6) Apakah promosi berpengaruh signifikan terhadap kepuasan pelanggan berbelanja di Battleboom Store Kota Palu, (7) Apakah fasilitas fisik berpengaruh signifikan terhadap kepuasan pelanggan berbelanja di Battleboom Store Kota Palu. Adapun tujuan penelitian ini dilakukan untuk mengetahui yaitu: (1) Untuk mengetahui pengaruh citra toko yang terdiri dari lokasi, produk, harga, pelayanan, promosi dan fasilitas fisik terhadap kepuasan pelanggan berbelanja di Battleboom Store Kota Palu, (2) Untuk mengetahui pengaruh lokasi toko terhadap kepuasan pelanggan berbelanja di Battleboom Store Kota Palu, (3) Untuk mengetahui pengaruh produk terhadap kepuasan pelanggan berbelanja di Battleboom Store Kota Palu, (4) Untuk mengetahui pengaruh harga terhadap kepuasan pelanggan berbelanja di Battleboom Store Kota Palu, (5) Untuk mengetahui pengaruh pelayanan terhadap kepuasan pelanggan berbelanja di Battleboom Store Kota Palu, (6) Untuk mengetahui pengaruh promosi terhadap kepuasan pelanggan berbelanja di Battleboom Store Kota Palu, (7) Untuk mengetahui pengaruh fasilitas fisik terhadap kepuasan pelanggan berbelanja di Battleboom Store Kota Palu.

\section{KAJIAN LITERATUR DAN PENGEMBANGAN HIPOTES}

\section{Citra Toko}

Membangun citra toko yang konsisten adalah tujuan umum para pengecer. Untuk itu perlu koordinasi berbagai aspek citra toko untuk menarik segmen pasar tertentu. Kadangkala, citra toko juga perlu diubah untuk menyesuaikan diri pada perubahan kebiasaan belanja konsumen dan posisi persaingan (Petter dan Olson, 2014:265).

Umumnya pemilik toko ingin konsumennya tidak hanya datang sekali dan tidak pernah kembali. Sebaliknya, mereka ingin konsumen untuk datang berulang kali. Kesetiaan kepada toko mengulangi 
niat dan perilaku berlangganan dapat sangat terpengaruh oleh penataan lingkungan, khususnya memperbarui kembali penampilan toko pengecer (Petter \& Olson, 2014:268)

\section{Variabel Citra Toko}

1. Lokasi Toko, Davidson dalam (Foster, 2008:52), mengatakan bahwa bila semua faktor mempunyai nilai yang hampir sama dalam pemilihan toko, pada umumnya konsumen akan memilih toko yang paling dekat, karena hal itu akan memberikan kenyamanan yang lebih bagi konsumen dalam hal waktu dan tenaga.

2. Produk, pedagang eceran harus memutuskan keluasan dan kedalaman ragam produk. Dimensi ragam produk lainnya adalah kualitas produk, pelanggan akan tertarik dengan kualitas produk serta rentang produk (Foster, 2008:55).

3. Harga, tingkat harga pada suatu toko dapat mempengaruhi cara berpikir konsumen terhadap unsurunsur lain dari bauran ritel, dalam penetapan dibutuhkan perhatian dan perhitungan yang jeli karena penetapan harga yang tinggi akan menyebabkan konsumen beralih ke toko yang lain yang menjual barang yang sejenis dengan harga yang lebih murah.

4. Pelayanan, pelayanan merupakan semua aktivitas, tindakan dan informasi yang dilakukan untuk mendapatkan kepercayaan konsumen terhadap nilai potensial dari barang atau jasa yang ditawarkan sehingga konsumen tertarik untuk memiliki (membeli) barang atau jasa tersebut (Vinci, 2009:169).

5. Promosi, menurut Kotler dan Keller (2012:478), campuran komunikasi pemasaran terdiri dari delapan komunikasi utama, yaitu periklanan, promosi penjualan, acara dan pengalaman, hubungan masyarakat dan publisitas, pemasaran langsung, pemasaran interaktif, pemasaran dari mulut-mulut dan penjualan pribadi.

6. Fasilitas Fisik, Gilbert dalam Foster (2008:6) menjelaskan bahwa fasilitas toko merupakan kombinasi dari pesan secara fisik yang telah direncanakan, fasilitas toko dapat digambarkan sebagai perusahaan terhadap perancangan lingkungan pembelian yang menghasilkan efek emosional khusus yang dapat menyebabkan konsumen melakukan tindakan pembelian.

\section{Kepuasan Pelanggan}

Kepuasan pelanggan berhubungan dengan mutu dari suatu produk yang di tawarkan, kepuasan konsumen mempunyai tingkat masing-masing tergantung apa yang pelanggan peroleh. Menurut Sunarto (2006:17) kepuasan pelanggan adalah perasaan senang atau kecewa seseorag yang muncul setelah membandingkan antara persepsi/kesannya terhadap kinerja suatu produk dan harapanharapannya.

Menurut Zeithaml dan Bitner (2000:75) respon atau tanggapan konsumen mengenai pemenuhan kebutuhan. Kepuasan merupakan penilaian mengenai ciri atau keistimewaan produk atau jasa yang menyediakan tingkat kesenangan konsumen berkaitan dengan pemenuhan kebutuhan konsumsi konsumen.

Kepuasan konsumen adalah tingkat perasaan konsumen setelah membandingkan antara apa yang dia terima dan harapannya (Umar, 2005:65). Seorang pelanggan, jika merasa puas dengan nilai yang diberikan oleh produk atau jasa, sangat besar kemungkinan untuk menjadi pelanggan dalam waktu lama. 


\section{Kerangka Pemikiran}

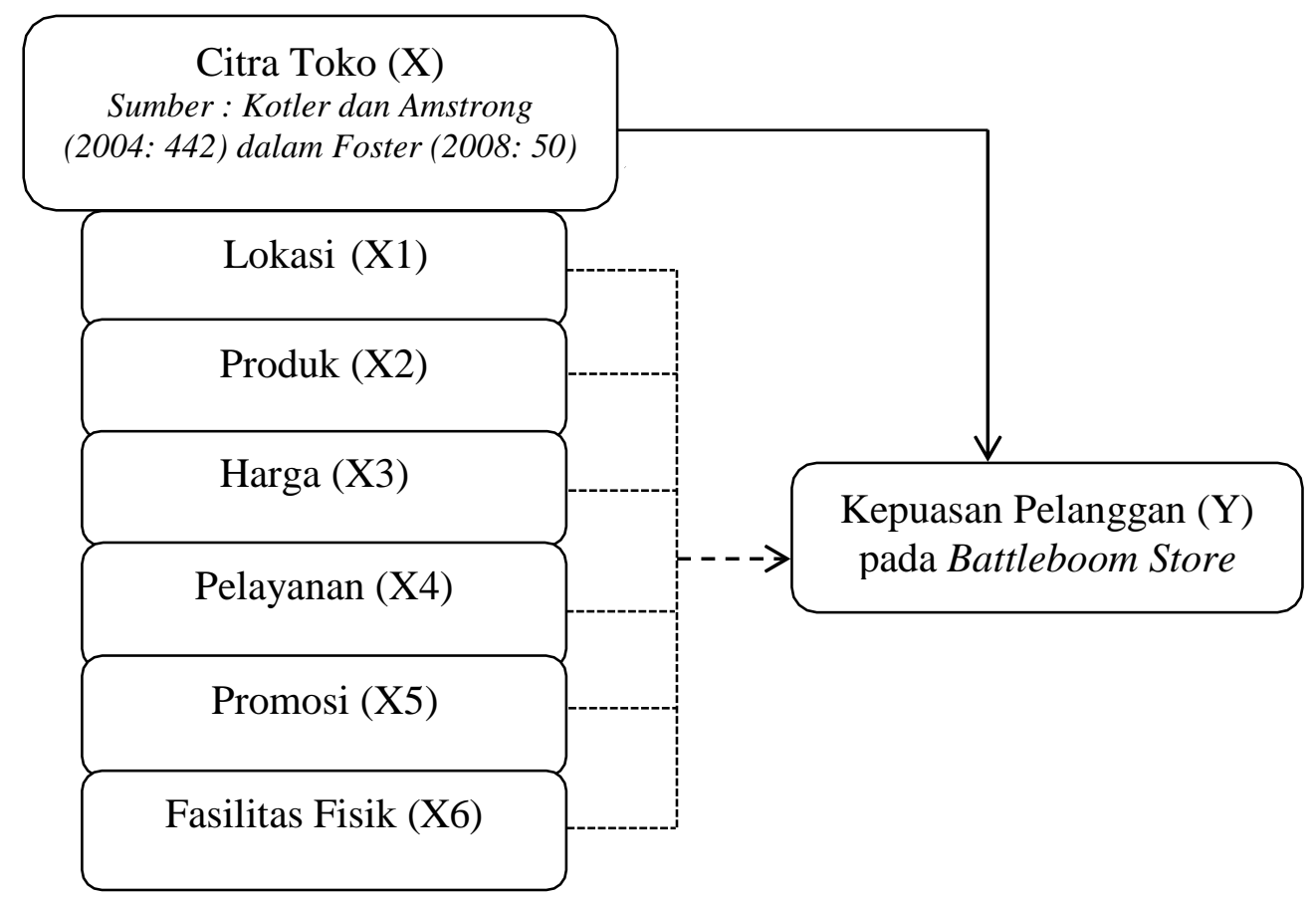

Gambar 1

Kerangka pemikiran penelitian

\section{Hipotesis}

Hipotesis merupakan dugaan sementara yang paling memungkinkan yang masih harus dicari kebenarannya. Berdasarkan rumusan masalah dan kajian pustaka yang akan dikemukakan, maka dapat disusun hipotesis penelitian sebagai berikut:

1. Variabel citra toko yang terdiri dari lokasi toko, produk, harga, pelayanan, promosi dan fasilitas fisik secara serempak berpengaruh signifikan terhadap kepuasan pelanggan pada Battleboom Store Kota Palu.

2. Variabel lokasi toko berpengaruh signifikan terhadap kepuasan pelanggan berbelanja di Battleboom Store Kota Palu.

3. Variabel produk berpengaruh signifikan terhadap kepuasan pelanggan berbelanja di Battleboom Store Kota Palu.

4. Variabel harga berpengaruh signifikan terhadap kepuasan pelanggan berbelanja di Battleboom Store Kota Palu.

5. Variabel pelayanan berpengaruh signifikan terhadap kepuasan pelanggan berbelanja di Battleboom Store Kota Palu.

6. Variabel promosi berpengaruh signifikan terhadap kepuasan pelanggan berbelanja di Battleboom Store Kota Palu.

7. Variabel fasilitas fisik berpengaruh signifikan terhadap kepuasan pelanggan berbelanja di Battleboom Store Kota Palu. 


\section{METODE PENELITIAN}

Metode yang digunakan dalam penelitian ini menggunakan pendekatan kuantitatif, yaitu penelitian yang bertujuan untuk mengetahui pengaruh dari variabel bebas. Jenis penelitian yang akan digunakan adalah deskriptif kausal. Menurut Sugiyono (2013:22) "penelitian deskriptif adalah metode yang digunakan untuk menganalisa data dengan cara mendeskripsikan atau menggambarkan data yang telah terkumpul sebagaimana adanya tanpa bermaksud membuat kesimpulan yang berlaku untuk umum atau generalisasi”. Penelitian ini mengambil lokasi pada distro Battleboom Store di Kota Palu, dengan cara melakukan observasi, wawancara dan penyebaran kuesioner.

Teknik pengambilan sampel untuk menentukan sampel yang akan digunakan dalam penelitian ini menggunakan Teknik non probability sampling, yaitu purposive sampling. Unit sampel dalam penelitian ini adalah konsumen yang pernah berbelanja di Battleboom Store. Populasinya merujuk pada konsumen yang pernah berbelanja di Battleboom Store. Dikarenakan jumlah populasinya tidak diketahui secara pasti maka untuk menentukan besarnya sampel yaitu dengan menggunakan rumus Unknown Populations (Frendy dalam Ekasari, 2014:98)

$\mathrm{n}=\mathrm{Z} 2$

$$
4 \mu 2
$$

\section{Keterangan:}

$\mathrm{n}=$ ukuran sampel

$\mathrm{Z}=$ tingkat keyakinan sampel yang dibutuhkan dalam penelitian, pada $\alpha=5 \%$ (derajat keyakinan ditentukan 95\%) maka $\mathrm{Z}=1,96$

$\mu=$ margin of error, tingkat kesalahan yang dapat ditolerir (ditentukan 10\%)

Menggunakan rumus diatas, maka diperoleh perhitungan sebagai berikut:

$$
\begin{aligned}
\mathrm{n}= & 1,962 \\
& 4(0,1) 2 \\
\mathrm{n}= & 96,4 \approx 100 \text { responden }
\end{aligned}
$$

Agar data yang telah dikumpulkan dapat dimanfaatkan dengan baik, maka data tersebut harus diolah dan dianalsis terlebih dahulu sehingga dapat dijadikan dasar dalam pengambilan keputusan. Sebelum menggunakan metode analisis uji regresi linear berganda maka dilakukan terlebih dahulu uji asumsi klasik.

\section{Analisis Deskriptif}

Salah satu jenis statistik deskriptis yang dapat disajikan dalam laporan penelitian adalah distribusi frekuensi rata-rata. Statistik ini digunakan untuk menggambarkan distribusi frekuensi dan rata-rata jawaban responden atas berbagai item variabel yang diteliti. Analisa dilakukan dengan menggunakan nilai indeks yaitu dengan menentukan nilai besarnya kelas sebagai berikut:

$$
\begin{array}{ll}
\text { Nilai maksimum } & : 5 \\
\text { Nilai minimum } & 1 \\
\text { Nilai skala } & :-=0,8
\end{array}
$$

\section{Analisi Regresi}

Uji regresi linieritas berganda ini digunakan untuk mengetahui seberapa besar pengaruh variabel bebas yaitu Lokasi Toko (X1), Produk (X2), Harga (X3), Pelayanan (X4), Promosi (X5), Fasilitas Fisik (X6) terhadap variabel terikatnya yaitu Kepuasan Pelanggan (Y). Model umum bentuk persaaan alat analisis statistik parametrik Regresi Linear Berganda dapat digambarkan sebagai berikut (Sugiyono, 2013: 277).

$$
Y=a+b_{1} X_{1}+b_{2} X_{2}+b_{3} X_{3}+b_{4} X_{4}+b_{5} X_{5}+b_{6} X_{6}
$$


Keterangan:

$\begin{array}{ll}\mathrm{Y} & : \text { Kepuasan Pelanggan } \\ \alpha & : \text { Konstanta } \\ \mathrm{b}_{1}-\mathrm{b}_{6} & : \text { Koefisien Regresi } \\ \mathrm{X}_{1} & \text { : Lokasi Toko } \\ \mathrm{X}_{2} & \text { : Produk } \\ \mathrm{X}_{3} & : \text { Harga } \\ \mathrm{X}_{4} & : \text { Pelayanan } \\ \mathrm{X}_{5} & \text { : Promosi } \\ \mathrm{X}_{6} & : \text { Fasilitas Fisik }\end{array}$

3. Uji Hipotesis Pertama (Uji Serempak/Uji F)

Uji F digunakan untuk mengetahui apakah seluruh variabel independen secara simultan mempunyai pengaruh yang signifikan terhadap variabel dependen Sugiyono (2013:278).

1. Jika nilai sig $\mathrm{F}$ (probability) $\leq \alpha=(0,05)$, artinya seluruh variabel $\mathrm{X}$ berpengaruh signifikan terhadap variabel $\mathrm{Y}$, terbukti semua variabel independen yang diamati secara serempak berpengaruh signifikan terhadap variabel dependen.

2. Jika nilai sig $\mathrm{F}$ (probability) $\geq \alpha=(0,05)$, artinya variabel $\mathrm{X}$ berpengaruh tidak signifikan terhadap variabel $\mathrm{Y}$, terbukti semua variabel independen yang diamati secara serempak berpengaruh tidak signifikan terhadap variabel dependen.

4. Pengujian Hipotesis Ke Dua sampai dengan Ke Enam (Uji Persial/Uji t)

Dimana derajat signifikasi yang digunakan adalah $\alpha=(0,05)$, dengan bentuk pengujian sebagai berikut:

1. Jika nilai sig $\mathrm{t}$ (probability) $\leq \alpha=(0,05)$, artinya masing-masing variabel independen secara parsial berpengaruh signifikan terhadap terhadap kepuasan pelanggan Battleboom Store di Kota Palu.

2. Jika nilai sig $\mathrm{t}$ (probability) $\geq \alpha=(0,05)$, artinya variabel independen secara parsial berpengaruh tidak signifikan terhadap kepuasan pelanggan Battleboom Store di Kota Palu.

\section{HASIL DAN PEMBAHASAN}

Tabel 1

Hasil Analisis Linear Berganda

\begin{tabular}{|c|c|c|c|c|c|}
\hline \multicolumn{6}{|c|}{ Dependen Variabel Y = Kepuasan Pelanggan } \\
\hline \multirow[t]{2}{*}{$\begin{array}{c}\text { Variabel Independen } \\
\text { (Citra Toko) }\end{array}$} & \multicolumn{2}{|c|}{$\begin{array}{c}\text { Unstandardized } \\
\text { Coefficients }\end{array}$} & \multirow{2}{*}{$\begin{array}{c}\begin{array}{c}\text { Standardized } \\
\text { Coefficients }\end{array} \\
\text { Beta }\end{array}$} & \multirow[t]{2}{*}{$\mathbf{t}$} & \multirow[t]{2}{*}{ Sig } \\
\hline & $\mathbf{B}$ & Standar Error & & & \\
\hline $\mathrm{C}=$ Constanta & -1.417 & .239 & & -5.938 & .000 \\
\hline Lokasi. $\left(\mathrm{X}_{1}\right)$ & .041 & .062 & .045 & .659 & .511 \\
\hline Produk. $\left(\mathrm{X}_{2}\right)$ & .220 & .061 & -.188 & -3.612 & .008 \\
\hline Harga $\left(X_{3}\right)$ & .167 & .060 & .135 & 2.807 & .006 \\
\hline Pelayanan $\left(\mathrm{X}_{4}\right)$ & .654 & .046 & .716 & 14.325 & .000 \\
\hline Promosi $\left(\mathrm{X}_{5}\right)$ & .604 & .076 & .455 & 7.934 & .000 \\
\hline Fasilitas Fisik $\left(\mathrm{X}_{6}\right)$ & .080 & .054 & .098 & 1.478 & .143 \\
\hline $\begin{array}{ll}\text { Multiple R } & =.9 \\
\text { R Square }\left(R^{2}\right) & =.8\end{array}$ & & & $\begin{array}{l}\text { g.F }=.000 \\
\text { ljusted R-Squa }\end{array}$ & & \\
\hline
\end{tabular}


Berdasarkan tabel 1 diatas, maka dapat ditulis dalam bentuk persamaan regresi linear berganda adalah sebagai berikut:

$$
Y=-1,417+0,041 X 1+0,220 \times 2+0,167 \times 3+0,654 \times 4+0,604 \times 5+0,080 \times 6
$$

Adapun penjelasan bentuk persamaan tersebut, adalah sebagai berikut:

1. Nilai Konstanta sebesar -1,417. Artinya, jika nilai variabel independen lokasi (X1), produk (X2), harga (X3), pelayanan (X4), promosi (X5), dan fasilitas fisik (X6) bernilai 0 atau konstan, maka variabel dependen kepuasan pelanggan (Y) sebesar -1,417. Setiap ada kenaikan pada variabel independen sebesar satu satuan maka akan meningkatkan variabel dependen sebesar nilai koefisien beta masing-masing variabel independen dikalikan dengan besarnya kenaikan yang terjadi.

2. Koefisien regresi dimensi lokasi (X1) sebesar 0,041 bermakna bahwa pengaruh dimensi lokasi terhadap kepuasan pelanggan berbelanja di Battleboom Store Kota Palu adalah bersifat positif jika variasi perubahan dimensi lokasi meningkat satu-satuan, maka kepuasan pelanggan meningkat sebesar 0,041 atau 4\%.

3. Koefisien regresi dimensi produk (X2) sebesar 0,220 bermakna bahwa pengaruh dimensi produk terhadap kepuasan pelanggan berbelanja di Battleboom Store Kota Palu adalah bersifat positif jika variasi perubahan dimensi produk meningkat satu-satuan, maka kepuasan pelanggan meningkat 0,220 atau $22 \%$.

4. Koefisien regresi dimensi harga (X3) sebesar 0,167 bermakna bahwa pengaruh dimensi harga terhadap kepuasan pelanggan berbelanja di Battleboom Store Kota Palu adalah bersifat positif jika variasi perubahan dimensi harga meningkat satu rupiah, maka kepuasan pelanggan meningkat 0,167 atau $17 \%$.

5. Koefisien regresi dimensi pelayanan (X4) sebesar 0,654 bermakna bahwa pengaruh dimensi pelayanan terhadap kepuasan pelanggan berbelanja di Battleboom Store Kota Palu adalah bersifat positif jika variasi perubahan dimensi pelayanan meningkat satu-satuan, maka kepuasan pelanggan meningkat 0,654 atau $65 \%$.

6. Koefisien regresi dimensi promosi (X5) sebesar 0,604 bermakna bahwa pengaruh dimensi promosi terhadap kepuasan pelanggan berbelanja di Battleboom Store Kota Palu adalah bersifat positif jika variasi perubahan dimensi promosi meningkat satu-satuan, maka kepuasan pelanggan meningkat 0,604 atau $60 \%$.

7. Koefisien regresi dimensi fasilitas fisik (X6) sebesar 0,080 bermakna bahwa pengaruh dimensi fasilitas fisik terhadap kepuasan pelanggan berbelanja di Battleboom Store Kota Palu adalah bersifat positif jika variasi perubahan dimensi fasilitas fisik meningkat satu-satuan, maka kepuasan pelanggan meningkat 0,080 atau $8 \%$.

8. Koefisien korelasi (Multiple R) sebesar 0,946 ini menunjukan bahwa hubungan antara variabel independen dengan variabel dependen sebesar 94,6\%. Melihat angka tersebut maka dapat disimpulkan hubungan yang signifikan antara variabel independen: lokasi, produk, harga, pelayanan, promosi dan fasilitas fisik dengan variabel dependen (kepuasan pelanggan).

9. Koefisien Determinasi (R2) sebesar 0,894. Hal ini berarti $89,4 \%$ kepuasan pelanggan dapat dijelaskan oleh variabel citra toko yaitu lokasi toko, produk, harga, pelayanan, promosi dan fasilitas fisik, sedangkan sisanya yaitu $10,6 \%$ kepuasan pelanggan dipengaruhi oleh variabel-variabel lainnya yang tidak diteliti dalam penelitian ini.

\section{Uji F}

Jonathan (2006:74), menjelaskan kriteria pengujian dilakukan dengan menggunakan angka signifikansi atau Sig. Berdasarkan Tabel 1, diperoleh angka signifikansi sebesar 0,000. Angka 0,000 < 0,05 oleh karena itu, hipotesis diterima. Hal ini berarti terdapat pengaruh secara simultan variabel citra 
toko yang terdiri dari lokasi, produk, harga, pelayanan, promosi dan fasilitas fisik terhadap kepuasan pelanggan berbelanja di Battleboom Store Kota Palu.

\section{Uji t}

Uji t dimaksudkan untuk mengetahui seberapa jauh pengaruh satu variabel independen (lokasi, produk, harga, pelayanan, promosi dan fasilitas fisik) secara individual dalam menerangkan variabel dependen (kepuasan pelanggan).

1. Berdasarkan Tabel 1, hasil pengujian dengan SPSS diperoleh angka signifikansi sebesar 0,511 atau sebesar 51,1\%. Angka 0,511>0,05 oleh karena itu, hipotesis pada penelitian ini ditolak. Hal ini berarti bahwa variabel citra toko yaitu lokasi toko berpengaruh tidak signifikan terhadap kepuasan pelanggan berbelanja di Battleboom Store Kota Palu.

2. Berdasarkan Tabel 1, hasil pengujian dengan SPSS angka signifikansi sebesar 0,008. Angka 0,008 $<0,05$ oleh karena itu, hipotsesis pada penelitian ini diterima. Hal ini berarti bahwa variabel citra toko yaitu produk berpengaruh signifikan terhadap kepuasan pelanggan berbelanja di Battleboom Store Kota Palu.

3. Berdasarkan Tabel 1, hasil pengujian dengan SPSS angka signifikansi sebesar 0,006. Angka 0,006 $<0,05$ oleh karena itu, hipotsesis pada penelitian ini diterima. Hal ini berarti bahwa variabel citra toko yaitu harga berpengaruh signifikan terhadap kepuasan pelanggan berbelanja di Battleboom Store Kota Palu.

4. Berdasarkan Tabel 1, hasil pengujian dengan SPSS angka signifikansi sebesar 0,000. Angka 0,000 $<0,05$ oleh karena itu, hipotsesis pada penelitian ini diterima. Hal ini berarti bahwa variabel citra toko yaitu pelayanan berpengaruh signifikan terhadap kepuasan pelanggan berbelanja di Battleboom Store Kota Palu.

5. Berdasarkan Tabel 1, hasil pengujian dengan SPSS angka signifikansi sebesar 0,000. Angka 0,000 $<0,05$ oleh karena itu, hipotsesis pada penelitian ini diterima. Hal ini berarti bahwa variabel citra toko yaitu promosi berpengaruh signifikan terhadap kepuasan pelanggan berbelanja di Battleboom Store Kota Palu.

6. Berdasarkan Tabel 1, hasil pengujian dengan SPSS angka signifikansi sebesar 0,143. Angka 0,143 $>0,05$ oleh karena itu, hipotesis pada penelitian ini ditolak. Hal ini berarti bahwa variabel citra toko yaitu fasilitas fisik berpengaruh tidak signifikan terhadap kepuasan pelanggan berbelanja di Battleboom Store Kota Palu.

\section{Koefisien Determinasi (R2)}

Koefisien determinasi (R2) pada intinya mengukur seberapa jauh kemampuan model dalam menerangkan variasi variabel dependen. Nilai koefisien determinasi adalah antara nol dan satu (Ghozali, 2006). Nilai koefisien determinasi dapat dilihat pada Tabel 1

Hasil perhitungan dengan menggunakan program SPSS versi 16 dapat diketahui bahwa koefisien determinasi yang diperoleh sebesar 0,894. Hal ini berarti 89,4\% kepuasan pelanggan dapat dijelaskan oleh variabel citra toko yaitu lokasi toko, produk, harga, pelayanan, promosi dan fasilitas fisik, sedangkan sisanya yaitu 10,6\% kepuasan pelanggan dipengaruhi oleh variabel-variabel lainnya yang tidak diteliti dalam penelitian ini.

\section{PEMBAHASAN PENELITIAN}

\section{Pengaruh Citra Toko Terhadap Kepuasan Pelanggan Berbelanja di Battleboom Store Di Kota Palu}

Hasil penelitian menunjukkan bahwa secara simultan variabel citra toko yang terdiri dari lokasi toko, produk, harga, pelayanan, promosi dan fasilitas fasilitas fisik berpengaruh signifikan terhadap kepuasan pelanggan. Hasil ini memberikan arti dengan memiliki citra toko yang baik maka akan 
menyampaikan kesan yang baik tentang lokasi toko, produk, harga, promosi, pelayanan dan fasilitas fisik terhadap pelanggan agar mereka dapat berbelanja dengan nyaman sehingga dapat menimbulkan kepuasan pelanggan terhadap Batlleboom Store di Kota Palu. Hal ini sejalan dengan penelitian terdahulu yang dilakukan oleh Fandia (2011) bahwa citra toko mempunyai pengaruh dalam meningkatkan kepuasan konsumen pada Distro No Way Out Malang.

\section{Pengaruh Lokasi Toko Terhadap Kepuasan Pelanggan Berbelanja di Battleboom Store Kota Palu}

Hasil penelitian menunjukkan bahwa variabel lokasi toko berpengaruh tidak signifikan terhadap kepuasan pelanggan. Berdasarkan indikator lokasi toko yang diukur pada penelitian ini, pelanggan tidak terlalu memperdulikan lokasi toko Batlleboom Store. Karena apabila toko telah memiliki citra yang baik terhadap pelanggannya maka dimanapun lokasi toko tersebut berada pelanggan akan berusaha untuk menjangkau toko tersebut.

Hasil penelitian ini sejalan dengan penelitian oleh Richa Angkita Mulyawisdawati (2012) yang menunjukkan bahwa produk dan harga berpengaruh secara positif dan signifikan terhadap kepuasan pelanggan, namun lokasi/distribusi berpengaruh secara negatif dan tidak signifikan terhadap kepuasan pelanggan.

\section{Pengaruh Produk Terhadap Kepuasan Pelanggan Berbelanja di Battleboom Store Kota Palu}

Hasil penelitian menunjukkan variabel produk berpengaruh signifikan terhadap kepuasan pelanggan. Hal ini berarti bahwa dimensi produk dari Battleboom Store memiliki kualitas dan ketahanan produk yang baik. Sehingga menimbulkan kepuasan pelanggan dalam berbelanja di Battleboom Store Kota Palu. Kualitas produk harus dipertahankan bahkan ditingkatkan sehingga dapat menjaga pelanggan yang sudah ada dan dapat menarik pelanggan yang baru. Hal ini sejalan dengan penelitian oleh Ofela dan Agustin (2016) yang menunjukkan bahwa variabel kualitas produk berpengaruh positif terhadap kepuasan konsumen yang membeli Kebab King Abi Kapas Krampung Surabaya.

\section{Pengaruh Harga Terhadap Kepuasan Pelanggan Berbelanja di Battleboom Store Kota Palu}

Hasil penelitian menunjukkan variabel harga berpengaruh signifikan terhadap kepuasan pelanggan. Berdasarkan penelitian maka harga yang di tawarkan oleh Battleboom Store sesuai dengan kualitas dan manfaat dari produk yang di tawarkannya. Hal ini sejalan dengan penelitian oleh I.G.A Yulia Purnamasari (2015) yang menunjukkan bahwa harga berpengaruh positif dan signifikan terhadap kepuasan konsumen produk M2 Fashion Online di Singaraja Tahun 2015.

\section{Pengaruh Pelayanan Terhadap Kepuasan Pelanggan Berbelanja di Battleboom Store Kota Palu}

Hasil penelitian menunjukkan bahwa variabel pelayanan berpengaruh signifikan terhadap kepuasan pelanggan. Hasil ini memberikan arti dengan pelayanan yang ramah, cepat dan cukup tanggap oleh karyawan akan menimbulkan kesan yang baik sehingga pelanggan merasa nyaman berbelanja di Battleboom Store Kota Palu, dengan begitu maka akan meningkatkan kepuasan pelanggan berbelanja pada Battleboom Store di Kota Palu. Hal ini sejalan dengan penelitian oleh Moha dan Loindong (2016) yang menunjukkan bahwa kualitas pelayanan berpengaruh signifikan terhadap kepuasan konsumen.

\section{Pengaruh Promosi Terhadap Kepuasan Pelanggan Berbelanja di Battleboom Store Kota Palu}

Hasil penelitian menunjukkan bahwa variabel promosi berpengaruh signifikan terhadap kepuasan pelanggan. Indikator yang digunakan dalam kuisioner adalah menjadi sponsor dalam kegiatan acara (event) seperti Rock In Celebes 2015, Palu Clothing Expo 2015, Paradise Noise, Palu Record Store Day, purukata 2016 dan masi banyak menjadi sponsor di acara-acaranya lainnya, potongan harga (diskon) yang biasa di lakukan setiap 3 bulan sekali ataupun setiap akhir tahun dan promosi melalui 
Kamaliono, M.

media sosial instagram. Berdasarkan hasil penelitian menunjukkan bahwa promosi yang dilakukan oleh Battleboom Store memiliki dampak yang positif sehingga mampu menarik pelanggan utuk berbelanja dan pada akhirnya dapat menimbulkan kepuasan pelanggan. Hal ini sejalan dengan penelitian oleh Huda dan Farida (2014) yang menunjukkan bahwa promosi berpengaruh positif dan signifikan terhadap kepuasan konsumen terhadap Toko Joko Elektronik di Pati.

\section{Pengaruh Fasilitas Fisik Terhadap Kepuasan Pelanggan Berbelanja di Battleboom Store Kota Palu}

Hasil penelitian menunjukkan bahwa variabel fasilitas fisik berpengaruh tidak signifikan terhadap kepuasan pelanggan. Karena fasilitas fisik yang meliputi Battleboom Store menyediakan fasilitas parkir yang cukup luas, area berbelanja di dalam Battleboom Store cukup bersih dan temperatur di dalam Battleboom Store cukup sejuk tidak dapat menjadi suatu faktor yang dapat berpengaruh terhadap kepuasan. Sebab kepuasan pelanggan dapat diukur dengan indikatonya kepuasan senang dengan produk yang ditawarkan oleh Battleboom Store, memilih produk Battleboom Store karena sesuai harapan dan merasa puas dengan pelayanan yng diberikan oleh karyawan Battleboom Store.

Hal ini berbeda dengan penelitian oleh Mongkaren (2013) dan Lumentut dan Palendeng (2014), dimana dalam penelitian-penelitian tersebut ditemukan bahwa variabel fasiliatas memiliki pengaruh signifikan dan positif terhadap kepuasan konsumen. Penelitian pertama memfokuskan pada fasilitas pengguna jasa Rumah Sakit Advent Manado, sedangkan pada penelitian kedua fasilitas terhadap MCDONALD'S Manado. Implikasi dari penelitian ini, menyebabkan perusahaan Hotel Yuta harus terus meningkatkan kepuasan konsumen dan produktivitas dari para karyawan dalam melakukan fasilitas kepada para konsumen yang akan memicu kepuasan konsumen.

\section{KESIMPULAN DAN SARAN}

\section{Kesimpulan}

Berdasarkan pembahasan tentang pengaruh citra toko terhadap kepuasan pelanggan berbelanja di Battleboom Store maka dapat disimpulkan bahwa: (1) Variabel citra toko yang terdiri atas lokasi toko, produk, harga, pelayanan, promosi dan fasilitas fisik secara serempak berpengaruh signifikan terhadap kepuasan pelanggan berbelanja pada Battleboom Store di Kota Palu, (2) Dimensi lokasi toko berpengaruh tidak signifikan terhadap kepuasan pelanggan berbelanja pada Battleboom Store di Kota Palu, (3) Dimensi produk berpengaruh signifikan terhadap kepuasan pelanggan berbelanja pada Battleboom Store di Kota Palu, (4) Dimensi harga berpengaruh signifikan terhadap kepuasan pelanggan berbelanja pada Battleboom Store di Kota Palu, (5) Dimensi pelayanan berpengaruh signifikan terhadap kepuasan pelanggan berbelanja pada Battleboom Store di Kota Palu, (6)Dimensi promosi berpengaruh signifikan terhadap kepuasan pelanggan berbelanja pada Battleboom Store di Kota Palu, (7) Dimensi fasilitas fisik berpengaruh tidak signifikan terhadap kepuasan pelanggan berbelanja pada Battleboom Store di Kota Palu.

\section{Saran}

1. Bagi Perusahaan.

a) Pihak Battleboom Store lebih menjaga keterediaan yang ada pada Battleboom Store. Karena jika stok yang tersedia lengkap akan memicu minat beli konsumen dan akan memberikan dampak yang positif terhadap kepuasan pelanggan sendiri.

b) Sebaiknya pihak Battlebom Store untuk menciptakan citra toko yang baik dimata konsumen agar harga yang ditawarkan agar sesuai dengan kualitas yang di berikan. Karena banyak perusahaan Distro (Distributor Store) yang dapat menjadi pesaing yang unggul. 
c) Pihak Battlebom Store harus lebih memperhatikan ketanggapan karyawan berikan kepada konsumen, karena hal tersebut menjadi sebuah faktor yang dapat mempengaruhi kepuasan konsumen dalam berbelanja.

d) Pihak Battleboom Store lebih meningkatkan promosi melalu media sosial bukan hanya memaksimalkan pada instagram, tetapi masih banyak media sosial yang banyak masyarakat gunakan seperti facebook, twitter dan path.

2. Bagi peneliti selanjutnya yang ingin meneliti atau melanjutkan penelitian ini, disarankan untuk meneruskan atau mengembangkan penelitian ini dengan mencari faktor lain yang dapat mempengaruhi nilai pelanggan dan kepuasan pelanggan dalam meningkatkan kualitas produk. Selain menyebarkan kuesioner, penelitian selanjutnya sebaiknya disertai dengan wawancara yang lebih mendalam sehingga data yang diperoleh lebih lengkap dan dapat mengurangi data yang bersifat subyektif.

\section{REFERENSI}

Berman, Barry and Juel. R. Evans. 2009. Retail Management Strategic. New Jersey: Pearson Education.

Ekasari, Novita. (2014). Pengaruh Promosi berbasis Social media terhadap

keputusan pembelian produk jasa Pembiayaan kendaraan PT. BFI Finance Jambi. Jurnal Volume 16, Nomor 2, Hal. 81-102 (ISSN: 0852-8349). Universitas Jambi.

Fandia, Octofiansyah EM. 2011. Pengaruh Citra Toko Terhadap Kepuasan Pelanggan (Studi pada Konsumen Distro No Way Out Malang). Skripsi Jurusan Manajemen, Fakultas Ekonomi UM

Foster, Bob. 2008. Manjemen Ritel. Bandung: Alfabeta.

Ghozali, Imam. 2006. Aplikasi Analisis Multivariate dengan Program SPSS. Semarang: Badan Penerbit Universitas Diponegoro.

Huda dan Farida, 2014. Pengaruh Pelayanan, Promosi dan Lokasi Terhadap Kepuasan Konsumen

Toko Joko Elektronik di Pati. Jurnal Manajemen Fakultas Ekonomi dan Bisnis Universitas

Dian Nuswantoro.

Jonathan, Sarwono.2006. Metode Penelitian Kuantitatif dan Kualitatif. Yogyakarta: Graha Ilmu.

Kotler dan Keller. 2012. Marketing Management. 14 $4^{\text {th }}$ edition. Prentice. New Jersey.

Lumentut dan Palendeng, 2014. Fasilitas, Servicescape, dan Kualitas Pelayanan, Pengaruhnya terhadap Kepuasan Konsumen MCDONALD’S Manado. Jurnal EMBA, Vol. 2, No. 3.

Mongkaren, Steffi, 2013. Fasilitas dan Kualitas Pelayanan Pengaruhnya Terhadap Kepuasan Pengguna Jasa Rumah Sakit Advent Manado. Jurnal EMBA, Vol. 1, No. 4, ISSN 2303-1174.

Moha dan Loindong, 2016. Analisis Kualitas Pelayanan dan Fasilitas Terhadap Kepuasan Konsumen Pada Hotel Yuta di Kota Manado. Jurnal EMBA, Vol. 4, No. 1.

Mulyawisdawati, Richa Angkita, 2012. Analisis Pengaruh Bauran Pemasaran Terhadap Kepuasan dan Loyalitas Pelanggan di Karita Muslim Square Yogyakarta.

Ofela dan Agustin, 2016. Pengaruh Harga, Kualitas Produk dan Kualitas Pelayanan Terhadap Kepuasan Konsumen Kebab Kingabi. Jurnal Ilmu dan Riset Manajemen, Vol. 5, No. 1.

Petter dan Olson, 2014. Perilaku Konsumen \& Strategi Pemasaran. Jakarta Selatan: Salemba Empat. Purnamasari, I.G.A Yulia, 2015. Pengaruh Kualitas Produk dan Harga Terhadap Kepuasan Konsumen Produk M2 Fashion Online di Singaraja Tahun 2015. Jurnal Jurusan Pendidikan Ekonomi (JJP), Vol. 5, No. 1.

Sugiyono. 2013. Metode Penelitian Kuantitatif Kualitatif dan R\&D. Bandung: Alfabeta.

Sunarto. 2006. Pengantar Manajemen Pemasaran, Yogyakarta: Cetakan 1. Ust. Press.

Sopiah dan Syihabudhin. 2008. Manejemen Bisnis Ritel. Yogyakarta: C.V Andi Offset.

Umar, Husen. 2005. Riset Pemasaran dan Perilaku Konsumen. Jakarta: Business Reseacrh Center.

Vinci, Maharani. 2009. Manajemen Bisnis Eceran. Bandung: Sinar Baru Algensindo. 
Kamaliono, M.

Zeithaml dan Bitner. 2000. Service Marketing. Integrating Customer Focus Across The Firm, Second Edition Hill. McGraw. New York. 